\title{
СОЦІАЛІЗАЦІЯ ОСОБИСТОСТІ МОЛОДШОГО ШКОЛЯРА В УМОВАХ КОЛЕКТИВУ І НАВЧАЛЬНОГО СЕРЕДОВИЩА
}

Шимко І. М. Соціалізація особистості молодшого школяра в умовах колективу і навчального середовища.

У статті здійснено теоретичний аналіз з проблеми розвитку особистості молодшого школяра в колективі, розкрито сутність та особливості соціалізації молодшого школяра в умовах колективу і навчального середовища.

Ключові слова: соціалізація, особистість, молодший школяр, колектив, навчальне середовище.

Шимко И. Н. Социализация личности младшего школьника в условиях коллектива и учебной среды.

В статьеосуществлентеоретическийанализпроблемыразвитияличностимладшего школьника в коллективе, раскрыты суть и особенности социализации младшего школьника в условиях коллектива и учебной среды.

Ключевые слова: социализация, личность, младший школьник, коллектив, учебная среда.

Shimko I. M. Socialization of personality of primary school child in a collective and inthelearning environment.

The article realizes with the theoretical analysisof the problem of personality primary school child in acollective, opens with the essence and the peculiar propertiesof the socialization of primary school child in a collective and the learning environment.

Key words: socialization, personality, primary school child, collective, learning environment.

Проблеми соціалізації і формування особистості молодшого школяра в колективі розглядали К. Волков, О. Киричук, О. Леонтьєв, О. Лутошкін, С. Максименко, К. Платонов та інші.

Метою статті є здійснення теоретичного аналізу з проблеми розвитку особистості в колективі та виховному закладі, встановлення психологічних особливостей соціалізації молодшого школяра в дитячому колективі, що надасть змогу в нових соціальних умовах розв'язати проблеми міжособистісних стосунків, соціалізації, самоствердження та самореалізації особистості.

Зміст поняття «соціалізація» $є$ нестабільним і неоднозначним. Його досліджували А. Андрєєнкова, В. Каптерєв, І. Кон, Т. Парсон, Е. Торндайк, Д. Уотсон, Н. Франклін (як процес повної інтеграції особистості в соціальну систему, в процесі якої відбувається їі пристосування), Г. Олпорт та К. Роджерс (як процес самоактуалізації «Я»-концепції).

I. Кон розглядає соціалізацію як оволодіння індивідом соціальним досвідом певної системи соціальних ролей і культури. Людина стає особистістю, об'єктом і суб'єктом суспільних відносин, послідовно проходячи різні стадії соціалізації.

Соціалізація - це процес і результат засвоєння і подальшого активного відтворення індивідом соціального досвіду. У процесі спільної діяльності і спілкування формується його соціальність - культура мислення і культура почуттів, культура духовного життя i культура поведінки. Поза людським суспільством духовний, соціальний, психічний розвиток відбуватися не може.

Усе, що характеризує сформовану особистість, має свої передумови в генетичній природі індивіда. Водночас ця природа не визначає якостей майбутньої особистості. Вони утворюються і розвиваються як результат взаємодії людини з навколишнім соціальним i природним середовищем, його власною життєдіяльністю і вихованням. У яких пропорціях будуть взаємодіяти окреслені чинники, до якого результату зумовить їх взаємодія, 
залежить від багатьох причин, дію яких ні врахувати, ні виміряти неможливо. Тому кожна людина розвивається «по-своєму», і ступінь впливу середовища на їі розвиток у неї також свій $[2$, с. 68].

Різні підходи до пояснення процесу соціалізації не суперечать один одному, а визначають його двосторонній характер. 3 одного боку, особистість засвоює соціальний досвід (етнічні, класові, групові, професійні та інші соціальні стереотипи і стандарти, сформовані суспільством) шляхом входження до системи існуючих соціальних зв'язків. 3 іншого боку, саме через природну активність вона зберігає і розвиває тенденцію до автономії, незалежності, свободи, формування власної позиції, неповторної індивідуальності. Саме це і забезпечує розвиток та перетворення як особистості, так i суспільства загалом.

П. Фрідман звертає увагу на те, що будь-який індивід закономірно проходить три фази свого становлення як особистість: адаптація особистості в групі - засвоєння індивідом чинних у групі норм і оволодіння відповідними формами і засобами діяльності; індивідуалізація - мобілізують усі внутрішні ресурси для того, щоб продемонструвати свою індивідуальність; інтеграція - взаємна трансформація індивіда і групи.

Отже, єдність процесів адаптації, інтеграції і самореалізації забезпечує оптимальний розвиток особистості у іiі взаємодії з середовищем, а їх перетин і $є$ суттю соціалізації.

Процес соціалізації ніколи не завершується, продовжується безперервно протягом усього життя. Йому властива внутрішня динаміка здобутків і втрат (Г. Костюк), безмежність саморозкриття особистості.

Спілкування 3 ровесниками $€$ неодмінною умовою соціалізації дитини. Воно створюється у малих групах (дитячий садок, шкільні класи, різні неформальні дитячі, підліткові і юнацькі об'єднання).

У дитячих і підліткових малих групах психологи виокремлюють три види відносин між ровесниками: функціонально-рольові, що виникають у специфічних для певної спільності сферах життєдіяльності дітей (навчальної, трудової, художньої) і розгортаються у процесі оволодіння дитиною нормами і способами дій у групі під керівництвом дорослого; емоційно-оцінні стосунки, основною функцією яких $є$ здійснення корекції поведінки ровесників відповідно до прийнятих норм спільної діяльності; їх наслідком є симпатії, антипатії, уподобання тощо; особистісно-смислові стосунки - взаємозв'язки у групі, за яких мотив однієї дитини набуває особистісного смислу для інших ровесників, з огляду на переживання інтересів і цінностей [2, с. 69].

П. Блонський зазначав, що дитячий колектив наділений величезною виховною, формувальною силою. Л. Божович наголошувала, що формування особистості дитини визначається насамперед тим становищем, яке вона займає в системі доступних їй людських взаємин, і тим, у якому співвідношенні перебувають вимоги, які висувають до неї життя й дорослі, з наявними у неї в цей час психологічними особливостями.

Одним із основних чинників соціалізації є соціально-комунікативна активність як одна із форм вибіркового ставлення дитини до ровесника та інших людей.

Г. Філіпчук указує, що залежно від індивідуальних особливостей, рис характеру, готовності і потреби у спілкуванні по-різному складаються взаємини в колективі. В учнів 1 класу таке товаришування починає формуватися насамперед між тими учнями, що сидять за однією партою, разом ходять до школи, розважаються, граються. Проте спілкування дуже нестійке. У 2-му класі вимоги до товариша зростають, набуваючи моральної спрямованості, зумовленої почуттям обов'язку у навчанні і поведінці. У їхніх взаєминах вже виявляються зародки дружби, яка іноді набуває глибокої прив'язаності, взаємної симпатії. У 3 -му класі взаємини між учнями набувають більш глибокої моральної спрямованості. Діти цього віку вже глибше розуміють свій обов'язок перед коллективом класу, школи і здебільшого без вагань йог виконують. Спілкування з однолітками дає дитині можливість побачити наслідки тієї чи тієї своєї поведінки, отримати соціальний досвід, який не завжди може дати сім'я [1, с. 131]. 
Молодший шкільний вік - важливий етап становлення особистості дитини. Це період так званої вторинної соціалізації. Школа продовжує і збагачує процес соціалізації, який розпочався в сім'ї. Перехід дитини до школи - це не лише зміна провідного виду діяльності, яка передбачає досягнення нею певного рівня фізичного і психічного розвитку, але й важливий етап іiї соціалізації. Перехід до шкільного навчання, зазначає Л. Божович, різко змінює спосіб (характер, напрям) життя дитини. Саме школа розкриває широкий діапазон міжособистісних контактів, який дитина засвоює за допомогою всієї гами своїх почуттів і переживань.

Із приходом дитини до школи, як підкреслюють Л. Божович, Д. Ельконін, Я. Коломінський, Л. Обухова, відбувається перебудова всієї системи взаємозв'язків дитини зі шкільною дійсністю. Діти починають приглядатися одне до одного, зав'язуються контакти, виникають спільні інтереси. Саме у спільній навчальній діяльності формується цілеспрямованість, виконуються спільні завдання, що породжують взаємну вимогливість і допомогу. Водночас спільна діяльність висуває певні вимоги до взаємин однолітків, до їхньої поведінки: необхідність прислухатися до думки однокласника, погоджувати свої дії з правилами і традиціями колективу, засвоювати певні норми поведінки. Порушення міжособистісних взаємин i стосунків у колі ровесників утруднюють процес соціалізації, оскільки виникає загроза для нормального психосоціального розвитку кожної дитини. Процес входження дитини в класний колектив складний i суперечливий. Для одних шкільний клас - це радість спілкування 3 однолітками, для інших - непорозуміння, неприязнь.

Л. Божович， В. Давидов， Д. Ельконін， Ю. Гільбух уважають спілкування одним 3 провідних чинників розвитку молодшого школяра. Г. Цукерман зауважує, що «спілкування у групі рівних (однолітків) надає дітям те, чого в принципі не може дати спілкування з дорослими. А за цим стоїть уміння бачити позиції іншої людини, оцінювати iii, приймати чи не приймати іiі, погоджуватись або заперечувати, а головне - мати свою точку зору, відрізняти її від іншої, вміти эї відстоювати». Спілкуючись з однолітками, діти швидше стають самостійними і незалежними.

Входження в новий класний колектив, пристосування до його колективних норм відбувається за участю батьків і вчителів, які допомагають з'ясувати нову роль учня, навчають дитину правильній поведінці. Управляння дітей у добрих вчинках i діях $\epsilon$ важливим складником соціалізації молодшого школяра.

Особливу увагу слід приділити формуванню шкільних колективів, оскільки саме у спільній діяльності закладаються головні цінності й норми соціального буття дитини.

Виховні організації відіграють подвійну роль у процесі соціалізації дітей. 3 одного боку, саме в них здійснюється соціальне виховання як відносно соціально контрольована соціалізація; з іншого боку, - вони, як і будь-які людські спільності, впливають на своїх членів стихійно у процесі взаємодії членів організації. І цей вплив за своїм характером не збігається з цінностями і нормами, які культивуються в процесі соціального виховання.

Основними функціями виховних організацій в процесі соціалізації можна вважати такі: залучення людини до культури суспільства; створення умов для індивідуального розвитку і духовно-ціннісної орієнтації; автономізація підростаючих поколінь від дорослих; диференціація виховуваних відповідно до їх особистісних ресурсів стосовно реальної соціально-професійної структури суспільства.

У процесі стихійної соціалізації виховна організація як будь-яка соціально-психологічна спільність упливає на залучених до неї людей в ході реальної практики взаємодії іiі членів, яка за своїм змістом, стилем і характером не ідентична, а деколи суттєво розходиться 3 декларованими прагненнями вихователів. Знання і досвід реального життя, які при цьому стихійно отримують виховувані, у великій своїй частині виявляються «непрактичними» для взаємодії у виховній організації з точки зору іiі основної функції - виховання, але допомагають адаптуватися в житті суспільства. 
На процес самозміни своїх членів виховна організація впливає залежно від ії побуту, змісту та форм організації життєдіяльності та взаємодії, які створюють більш або менш сприятливі можливості задля розвитку людини, задоволення нею позитивних потреб, здібностей та інтересів. Водночас практика реального життя організації впливає на вектор самозміни (просоціальний, асоціальний, антисоціальний).

У відносно соціально контрольованій соціалізації виховні організації відіграють провідну роль, оскільки саме в них людина більшою або меншою мірою набуває інституціолізованих знань, норм, досвіду, тобто саме в них здійснюється соціальне виховання [3, с. 60].

Отже, вступ дитини у шкільний коллектив має величезне значення для формування його особистості. Під впливом колективу в дитини молодшого шкільного віку поступово формується вищий тип соціальної спрямованості особистості, характерний для кожного, хто живе усвідомленими колективними інтересами. У молодшому шкільному віці дитина починає особливо активно прагнути до суспільства інших дітей, починає цікавитися громадськими справами свого класу, прагне сама визначити своє місце в колективі однолітків. Звичайно, входження у колектив і формування соціальної спрямованості особистості школяра відбувається далеко не відразу. Це - тривалий процес, що здійснюється під керівництвом вчителя, процес, який можна простежити, спостерігаючи й аналізуючи поведінку школярів різних класів.

\section{Література}

1. Каменсва Н. С. Психологічний аспект соціалізації особистості в колективі в умовах гуманізації суспільства / Н. С. Каменєва // Social-science. - 2010. - № 2. - С. 131. 2. Мойсеюк Н.Є. Педагогіка: [навч. посіб.] / Неля Євтихіївна Мойсеюк. - К., 2007. - 656 с. 3. Мудрик А. В. Социальная педагогика: [учебник] / Анатолий Викторович Мудрик. - М. : Издательский центр «Академия», 2000. - 200 с. 4. Проблемы формирования личности / [Божович Л.И.]; под ред. Д. И. Фельдштейна. - В. : Издательство «Институт практической психологии», 1997. - 352c. 5. Токарєва Л. Соціалізація і розвиток обдарованого молодшого учня / Л. Токарєва // Соціальна психологія. - 2006. - № 1 (15). - С. 94-102. 